\title{
Stocking Rate and Riparian Vegetation Effects on Physical Characteristics of Riparian Zones of Midwestern Pastures
}

\author{
Douglas A. Bear, ${ }^{1}$ James R. Russell, ${ }^{2}$ Mustafa Tufekcioglu, ${ }^{3}$ Thomas M. Isenhart, ${ }^{4}$ \\ Daniel G. Morrical, ${ }^{2}$ and John L. Kovar
}

\begin{abstract}
Authors are ${ }^{1}$ Research Assistant and ${ }^{2}$ Professor, Department of Animal Science, Iowa State University, Ames, IA 50011, USA; ${ }^{3}$ Assistant Professor, Department of Forestry, Artvin Coruh University, Artvin, Turkey 08000; ${ }^{4}$ Associate Professor, Natural Resource and Ecology Management, Iowa State University, Ames, IA 50011, USA; and ${ }^{5}$ Soil Scientist, National Laboratory for Agriculture and the Environment, Ames, IA 50011, USA.
\end{abstract}

\begin{abstract}
Grazing at high stocking rates may increase sediment and nutrient loading of pasture streams through transport in precipitation runoff and bank erosion. A 3-yr (2007-2009) grazing study was conducted on 13 cool-season grass pastures to quantify effects of stocking rate and botanical composition on forage sward height, proportions of bare and manure-covered ground, and bank erosion adjacent to streams. Pastures ranged from 2 ha to 107 ha with stream reaches of $306 \mathrm{~m}$ to $1778 \mathrm{~m}$ that drained watersheds of 253 ha to 5660 ha. Bare and manure-covered ground were measured at a $15.2-\mathrm{m}$ distance perpendicular to the stream at $30.5-\mathrm{m}$ intervals at up to 30 locations on each side of the stream by the line transect method in May, July, September, and November of each year. At the midpoint of the $15.2-\mathrm{m}$ line, forage sward height was measured with a falling plate meter $\left(4.8 \mathrm{~kg} \cdot \mathrm{m}^{-2}\right)$ and plant species identified. In November 2006, fiberglass pins $(1.6 \times 76.2 \mathrm{~cm})$ were driven $73.7 \mathrm{~cm}$ into the stream bank at $1-\mathrm{m}$ intervals from the streambed to the top of the bank along 10 equidistant transect locations on each side of the stream to measure bank erosion during spring, summer, and fall of each year. Increasing pasture stocking rates increased manure-covered ground and decreased sward height, but did not affect proportions of bare ground. The greatest, intermediate, and least net soil erosion rates occurred during the winter/early spring, late spring/early summer, and late summer/fall seasons. Stocking rates between measurements, expressed as cow-days $\cdot \mathrm{m}^{-1}$ stream, were not related to bank erosion. Increasing stocking rates per unit of stream length will increase manure cover and decrease forage sward height, but not affect proportions of bare ground or bank erosion rates adjacent to pasture streams. Therefore, managing stocking rates may reduce nutrient loading of pasture streams.
\end{abstract}

\section{Resumen}

La alta densidad de pastoreo puede incrementar la carga de los sedimentos y nutrientes en los arroyos que atraviesan los pastizales mediante el transporte de los escurrimientos y bancos de erosión. Un estudio de pastoreo de tres años (2007-2009) se llevó a cabo en trece pastizales compuestos de especies de pastos invernales para evaluar los efectos de la densidad de pastoreo y la composición botánica sobre la altura del corte del pasto, proporción de suelo desnudo y proporción de suelo cubierto con estiércol, y los bancos de erosión contiguos a los arroyos. Los pastizales oscilaron de 2 ha a 107 ha, con longitudes de arroyos de $306 \mathrm{~m}$ a $1178 \mathrm{~m}$ que drenaron cuencas de $253 \mathrm{ha}$ a $5660 \mathrm{ha}$. Suelo desnudo y cubierto por estiércol fue medido a un distancia de $15.2 \mathrm{~m}$ perpendicular al arrollo, a intervalos de $30.5 \mathrm{~m}$, en 30 sitios a cada lado del arroyo mediante el método de transecto lineal durante Mayo, Julio, Septiembre, y Noviembre de cada año. En el punto medio de la línea de $15.2 \mathrm{~m}$, la altura del corte de las plantas se midió con la técnica del plato descendiente $\left(4.8 \mathrm{~kg} \cdot \mathrm{m}^{-2}\right)$ y se identificaron las especies de plantas. En Noviembre de 2006, pernos de fibra de vidrio $(1.6 \times 76.2 \mathrm{~cm})$ fueron puestos a $73.7 \mathrm{~cm}$ dentro del banco del arroyo a intervalos de $1 \mathrm{~m}$ del cauce a la parte superior del banco a lo largo de 10 localidades equidistantes del transecto en cada lado del arroyo para medir el banco de erosión durante la primavera, verano y otoño de cada año. El incremento en la intensidad de pastoreo incrementó la cobertura de estiércol y redujo la altura de la vegetación pero no afectó la proporción del suelo desnudo. El mayor intermedio y la menor tasa de erosión se presentaron durante las épocas de invierno/inicio de la primavera, finales de la primavera/inicio del verano, y al final del verano/otoño. La densidad de pastoreo cuando las mediciones se expresaron como días-vaca $\mathrm{m}^{-1}$ arroyo, no fueron relacionadas con el banco de erosión. Incrementos en la densidad de pastoreo por unidad de longitud de arroyo aumentaron en el incremento en la cobertura de estiércol y disminuyeron la altura de los pastos, pero no afectaron las proporciones de suelo desnudo o la tasa de erosión del banco adyacente a los arroyos de los pastizales. Entonces, se concluye que si se maneja la densidad de pastoreo se podría reducir la carga de nutrientes en los arroyos de los pastizales.

Key Words: cover, grazing, stream bank erosion, sward height

Research was funded by the Cooperative State Research, Education, and Extension Service, USDA, under Award 2006-51130-03700. Any opinions, findings, conclusions, or recommendations expressed in this publication are those of the authors and do not necessarily reflect the views of the USDA.

Mention of a proprietary product does not constitute a guarantee or warranty of the product by lowa State University or the authors and does not imply its approval to the exclusion of other products that also may be suitable.

Correspondence: J. R. Russell, Dept of Animal Science, 313 Kildee Hall, lowa State University, Ames, IA 50011, USA. Email: jrussell@iastate.edu

Manuscript received 25 July 2011; manuscript accepted 6 November 2011. 


\section{INTRODUCTION}

Pasturelands have been cited as major contributors to sediment and nutrient loading of surface water resources (Zaimes et al. 2004, 2008; Alexander et al. 2008). Although these effects may be related to poor grazing management, little information has been published on the effects of pasture stocking rate and riparian vegetation on the risk of nonpoint source pollution (NPS) of streams in Midwestern pastures.

Studies on Western rangelands have shown that maintaining adequate vegetation contributes to prevention of degradation of riparian areas (Butler et al. 2006; Schoonover et al. 2006) and NPS of pasture streams by providing cover and resistance to erosion (Klemmedson 1956; Kauffman and Krueger 1984; Trimble 1994). Vegetation cover provides resistance to topsoil detachment by reducing raindrop forces (Hofman and Ries 1991; Pearce et al. 1998) and may limit concentrated flow and runoff events (Self-Davis et al. 2003; De Baets et al. 2007). Furthermore, vegetation cover will entrap and retain sediment that is transported in precipitation runoff before it can enter streams (Clary et al. 1996; Clary and Leininger 2000; Butler et al. 2006).

Vegetation stubble height has been proposed as a tool to assess the ability of a sward to filter sediment from precipitation runoff (Clary and Webster 1990). However, stubble height alone is not a suitable guideline to estimate sediment infiltration because vegetation density, soil surface characteristics, sediment particle size, and buffer length also influence sediment movement in riparian zones (Pearce et al. 1997, 1998; Frasier et al. 1998). But although stubble height of riparian vegetation may have a limited role in sediment filtration, it may be important in maintaining plant vigor and stream bank stability (Frasier et al. 1998).

Beyond the height of the forage, effectiveness of forages to prevent erosion is dependent on the density and strength of the vegetation and roots of the plant species that dominate the riparian zone. Sod grasses, such as reed canarygrass (Phalaris arundinacea L.), Kentucky bluegrass (Poa pratensis L.), and smooth bromegrass (Bromus inermis L.) are generally more tolerant of frequent defoliation events and develop a more uniform sod and tiller density compared to bunch-type grasses such as tall fescue (Festuca arundinacea Schreb.), timothy (Phleum pretense L.), orchardgrass (Dactylis glomerata L.), and ryegrass (Lolium perenne L.; Sanderson et al. 1997; Carlassare and Karsten 2002; Lee et al. 2009). Therefore, sod grasses may be more effective than bunchgrasses in preventing precipitation runoff and sediment transport and because of the deep root structure of perennial grasslands, sediment and nutrient transport is controlled and water infiltration increased during high-intensity rainfall events (De Baets et al. 2007; Kemp and Michalk 2007).

Research conducted on Western rangeland conditions has shown that overgrazing of forages or the increased space between bunchgrasses near surface waters decreases the effectiveness of the forage to reduce the velocity of overland water flow (Temple 1982; Masterman and Thorne 1992), thereby increasing the risk of sediment and nutrient loading of the streams (Alderfer and Robinson 1947; Warren et al. 1986). Overgrazing may be caused by high stocking rates (Manley et al. 1997), long grazing duration (Krueger et al. 2002), or congregation of cattle near streams (Tate et al. 2003), particularly during seasons with low vegetation productivity (Miner et al. 1992). White et al. (2001) and Ballard and Krueger (2005) reported that an increase in the duration of cattle presence in an area increased the amount of manure in that area. The high soil-nutrient concentrations resulting from the concentration of feces in congregation areas may be transported in precipitation runoff and negatively impact aquatic ecosystems (Reynoldson 1987; Belsky et al. 1999; Wang et al. 2007). As the previous results were observed from research conducted on Western rangelands, these findings may not be applicable to management of Midwestern pastures because of differences in rainfall, climate, forage and soil types, and management.

Therefore, the objectives of this project were to evaluate the effects of stocking rates and botanical composition on forage sward heights and proportions of bare and manure-covered ground in the riparian zone, and the amount of bank erosion along streams in riparian areas of southern Iowa pastures.

\section{MATERIALS AND METHODS}

\section{Study Location}

The study was conducted in the Lake Rathbun watershed in southern Iowa (lat $40^{\circ} 45^{\prime} \mathrm{N}$, long $93^{\circ} 18^{\prime} \mathrm{W}$, approximately $300 \mathrm{~m}$ above sea level). The Rathbun Lake watershed includes more than 143283 ha, encompasses six southern Iowa counties, and contains Rathbun Lake, which is more than 4451 ha in size. Located within the Loess Flats and Till Plains ecoregion, the landscape within the Rathbun Lake watershed is characterized by deep to moderate loess deposits over glacial till and dark, shallow soils. The topography of the area varies from flat to moderately hilly. The region lacks glacial till in many places, but comprises greater drainage density and woody vegetation within the stream reaches compared to other areas of the ecoregion (Griffith et al. 1994; Rathbun Land and Water Alliance 2001). The 30-yr mean annual precipitation for the watershed is $93.4 \mathrm{~cm}$.

Soil erosion from stream banks in riparian areas has been identified as an important source of sediment and associated phosphorus delivery to Rathbun Lake, accounting for $26 \%$ of the total estimated sediment delivery from the watershed (Isenhart and Sitzmann 2001). Livestock grazing was implicated as the primary factor of this erosion during visual assessment of the watershed.

\section{Pasture Characteristics}

Thirteen pastures on 12 cooperating cow-calf farms in the Rathbun Lake watershed were identified as suitable for the project in the fall of 2006. Sites selected were based on the producers' willingness to maintain cattle stocking records and allow pasture access to conduct measurements during May, July, September, and November from 2007 to 2009, and on the presence of a perennial flowing stream. Pasture sizes ranged from 2.8 ha to 107.2 ha with first- to third-order streams that drained watershed areas of 253 ha to 5660 ha (Table 1). Stream lengths within each pasture, measured with a rotary tape measure in November 2006, ranged from $306 \mathrm{~m}$ to $1778 \mathrm{~m}$. At the initiation of the study, two of the 13 pastures 
Table 1. Pasture stream reaches, areas, watershed areas, cattle breeds, and water sources on farms of cooperating producers.

\begin{tabular}{|c|c|c|c|c|c|}
\hline Pasture & Stream reach (m) & Pasture area (ha) & Watershed area (ha) & Cattle breeds & Water sources \\
\hline Pasture 1 & 598 & 20.2 & 318 & Angus/cross & Stream \\
\hline Pasture 2 & 1778 & 51.4 & 1090 & Red Angus & Stream \\
\hline Pasture 3 & 1162 & 10.4 & 480 & None & Stream \\
\hline Pasture 4 & 306 & 2.8 & 579 & Angus/cross & Stream and tanks \\
\hline Pasture 5 & 1610 & 29.1 & 444 & Angus/cross & Stream and ponds \\
\hline Pasture 6 & 922 & 28.7 & 5660 & Angus & Stream and tanks \\
\hline Pasture 7 & 890 & 25.1 & 709 & Cross & Stream \\
\hline Pasture 8 & 1260 & 33.2 & 756 & Cross & Stream \\
\hline Pasture 9 & 1040 & 107.2 & 472 & Angus & Stream \\
\hline Pasture 10 & 1138 & 55.4 & 2007 & Angus & Stream and pond \\
\hline Pasture 11 & 1039 & 48.2 & 3630 & Hereford/cross & Stream and tanks \\
\hline Pasture 12 & 1120 & 28.7 & 393 & Angus/cross & Stream and tanks \\
\hline Pasture 13 & 1179 & 13.8 & 253 & None & Stream \\
\hline
\end{tabular}

were ungrazed vegetation buffers. Stream order of each stream was determined using the Strahler (1957) classification system. Bed slope and sinuosity measurements of each stream were calculated at two different scales on 2002 digital orthophotos using geographic information system Arc Map 9.2 tools (Table 2). One set of measurements was calculated at the grazed pasture stream reach (station) scale where the erosion pin plots were located. The other set included measurements at the catchment scale of stream reaches located above each of the treatment pastures. Stream bed slope values were calculated as the difference in elevations (rise) between the lowest and highest point of stream reach divided by the horizontal stream length (run) of a given stream reach. Sinuosity was estimated by first digitizing the total meandered length of a given stream reach at $1 \mathrm{~m}$ resolution from 2002 color infrared digital orthophotos and then dividing that value by the straight line valley length of the reach.

Of the 11 stocked pastures, eight of the pastures in the study were continuously stocked at $2.71-31.67 \mathrm{cow}$-days $\cdot \mathrm{m}^{-1}$ stream annually with cattle having year-round access to surface waters. Three of the pastures were rotationally stocked at 2.21-

Table 2. Stream morphologic characteristics at field and catchment scales.

\begin{tabular}{cccc}
\hline Pasture & Stream bed slope $^{1}$ & Stream sinuosity $^{1}$ & Stream $^{\text {order }}{ }^{2}$ \\
\hline Pasture 1 & $2.0(1.8)$ & $1.2(1.4)$ & $\mathrm{I}$ \\
Pasture 2 & $0.7(0.8)$ & $1.4(1.3)$ & $\mathrm{II}$ \\
Pasture 3 & $1.6(1.4)$ & $1.3(1.3)$ & $\mathrm{I}$ \\
Pasture 4 & $2.0(1.3)$ & $1.5(1.3)$ & $\mathrm{I}$ \\
Pasture 5 & $1.3(2.0)$ & $1.6(1.4)$ & $\mathrm{I}$ \\
Pasture 6 & $1.5(0.3)$ & $1.2(1.4)$ & $\mathrm{III}$ \\
Pasture 7 & $1.6(0.7)$ & $1.1(1.2)$ & $\mathrm{I}$ \\
Pasture 8 & $0.8(0.8)$ & $1.4(1.4)$ & $\mathrm{I}$ \\
Pasture 9 & $0.6(1.6)$ & $2.0(1.2)$ & $\mathrm{I}$ \\
Pasture 10 & $0.4(0.6)$ & $1.5(1.3)$ & $\mathrm{I}$ \\
Pasture 11 & $0.3(0.3)$ & $1.1(1.4)$ & $\mathrm{III}$ \\
Pasture 12 & $0.8(1.7)$ & $1.4(1.2)$ & $\mathrm{I}$ \\
Pasture 13 & $1.7(2.1)$ & $1.1(1.1)$ & $\mathrm{I}$ \\
\hline
\end{tabular}

${ }^{1}$ Numbers inside the parentheses represent the given stream feature at the catchment scale. ${ }^{2}$ Stream order category based on Strahler (1957).
$19.24 \mathrm{cow}$-days $\cdot \mathrm{m}^{-1}$ stream annually. Because one of the two vegetation buffers was grazed from October through November 2007, the stocking rates of the vegetation buffers ranged from $0.00 \mathrm{cow}$-days $\cdot \mathrm{m}^{-1}$ stream to 0.45 cow-days $\cdot \mathrm{m}^{-1}$ stream annually. Water sources across farms included streams, streams and off-stream water tanks, and streams and ponds on seven, four, and two of the farms, respectively. Cattle stocked on the pastures on 11 of the farms were all Bos taurus breeds of Angus or Angus crossbreds with the remaining two farms including Red Angus and Hereford.

\section{Precipitation Data}

A HOBO weather station (Onset Comp. Co., Bourne, MA) with a Rain Gauge Smart Sensor (Onset Comp. Co.) was placed adjacent to 6 of the 13 pastures to record rainfall at 10-min intervals from April through November in each of the $3 \mathrm{yr}$. Weather stations were removed from the pastures when temperatures reached freezing conditions to protect the tipping bucket equipment. Precipitation data for pastures without weather stations were assumed to be equal to that of the nearest pasture with a weather station. Precipitation data for the remainder of the year and until the weather stations were replaced the following spring were downloaded from the NOAA weather stations in Allerton (approx. $6.6 \mathrm{~km}$ from 7 study pastures) or Chariton, Iowa (approx. $10 \mathrm{~km}$ from 6 study pastures).

\section{Cattle Stocking Rates}

All cooperating producers maintained stocking records of the duration and number of cows, heifers, and bulls stocked on each pasture during the 3-yr study. The number of cow-days stocked on each pasture during the periods between the dates of each measurement of bare soil, fecal-covered ground, forage sward height, and stream bank erosion were calculated as

$$
\begin{aligned}
\text { Cow }- \text { day }= & (\text { No. of cows } \times 1.00 \times \text { days stocked }) \\
& +(\text { No. of heifers } \times 0.84 \times \text { days stocked }) \\
& +(\text { No. of bulls } \times 1.29 \times \text { days stocked })
\end{aligned}
$$

based on the animal's metabolic size to standard livestock units (Allen 1991). Stocking rates were calculated per measurement 
period per stream distance (cow-days $\cdot \mathrm{m}^{-1}$ stream) by dividing total cow-days by the stream reach length within each pasture. The rationale for expressing the stocking rate on a per meter of stream reach basis as opposed to a per unit of land area basis was to adjust for the effects of varying sizes and shapes of pastures on cow grazing distribution near pasture streams. Although calves may contribute to deterioration of riparian areas and streams through their hoof action, fecal matter, and vegetation removal, they were not considered in the calculation of stocking rates, but these effects should be proportional to the cow stocking rates across farms.

\section{Riparian Area Characteristics}

Proportions of bare ground, manure-covered ground, forage sward height, and vegetation species were evaluated in May, July, September, and November in 2007 through 2009 on both sides of the stream at up to 30 locations at $30.5-\mathrm{m}$ intervals. Proportions of bare and manure-covered ground were measured perpendicular to the stream by the line transect method (Canfield 1941; Anderson et al. 1979) over a 15.2-m distance beginning at the edge of the stream. One hundred beads, spaced at $15.2-\mathrm{cm}$ intervals on the line, were used to evaluate the percentages of bare and manure-covered ground located directly underneath each bead at each location. Forage sward height was measured with a falling plate meter $\left(4.8 \mathrm{~kg} \cdot \mathrm{m}^{-2}\right.$; Hermann et al. 2002) and vegetation species were identified at the midpoint of the transect line. The falling plate meter was constructed of a $3.18-\mathrm{mm}$ thick plexiglass plate with an area of $2500 \mathrm{~cm}^{2}$ attached to a $1.27-\mathrm{cm}$-diameter polyvinyl chloride tube of variable length so that the apparatus weighed $1.2 \mathrm{~kg}$. This apparatus slid down a calibrated aluminum rod with an outer diameter of $1.27 \mathrm{~cm}$, thereby yielding an estimated measure of live forage mass from the height. Sward height was not measured at sites in which shrubs were the vegetation species. Botanical composition of the riparian zones was calculated as a proportion of the herbaceous vegetation species located at each vegetated site.

\section{Stream Bank Erosion Measurements}

In each pasture, 10 transects were placed at $30.5-\mathrm{m}$ intervals, five on the upstream and five on the downstream side of the midpoint of the pasture stream length. In order to estimate the amount of sediment loss from stream banks, erosion rates were measured with $1.6 \times 76.2 \mathrm{~cm}$ fiberglass pins driven $73.7 \mathrm{~cm}$ into the stream bank at 1-m intervals from the streambed to the top of the bank on each side of the stream (Wolman 1959). If the stream bank height did not exceed $1 \mathrm{~m}$, only one pin was placed at approximately half the distance of the height of the bank. Pin measurements were taken in midspring, midsummer, and late fall to evaluate erosion that occurred during the winter through early spring, late spring through early summer, and late summer through fall periods. At each measurement date, net erosion was calculated by the subtracting the pin length exposed or covered since from the previous measurement. Individual pin measurements were averaged across all of the 10 transects to determine net erosion rates occurring from the stream banks of pastures. Positive exposed fiberglass values represented erosion and negative values represented deposition. In the event that fiberglass pins were lost from the stream bank, an erosion rate of $60 \mathrm{~cm}$ was assumed (Hooke 1979; Lawler 1993; Zaimes et al. 2004).

\section{Statistical Analyses}

Riparian characteristics were analyzed as repeated measures using an AR (1) covariance MIXED procedure model of SAS (SAS Institute Inc., Cary, NC) between pastures. The model statement included fixed effects of pasture, month, and year with month as the repeated factor and year as the experimental unit. Random effects included the pasture by year interaction. Differences between means with significant treatment effects in all analyses were determined by comparing the least-squares means using the PDIFF statement with a Tukey adjustment for multiple comparisons. Significance was determined at a level of $P<0.05$.

Regression equations were calculated to quantify the relationship between the dependent variables of proportion of bare soil, proportion of manure-covered ground, forage sward height, and net stream bank erosion at each measurement with the independent variables of the stocking rate per meter of stream reach for the time interval preceding the measurement and the proportion of each vegetation species of the total vegetated sites (SAS Institute). In order to determine significant regressions from the 13 pastures in the study, a Bonferroni adjustment was performed ( 0.05 divided by the 11 regressions performed) to determine significant pasture characteristic effects. Significance was determined at a level of $P<0.0045$.

\section{RESULTS}

\section{Riparian Vegetation}

Vegetation species observed included tall fescue; reed canarygrass; Kentucky bluegrass; smooth bromegrass; orchardgrass; timothy; legumes, which were primarily white clover (Trifolium repens L.) or red clover (Trifolium pretense L.); squarrose sedge (Carex squarrosa L.); weed grasses, primarily green foxtail (Setaria viridis L.); broadleaf weeds, which were primarily giant ragweed (Ambrosia trifida L.), stinging nettles (Urtica dioica L.), and wild parsnips (Pastinaca sativa L.); and shrubs, primarily multiflora rose (Rosa multiflora L.).

The proportion of vegetation species comprising tall fescue, reed canarygrass, legumes, sedge, broadleaf weeds, and shrubs differed $(P<0.01)$ between pastures (Table 3). Pastures 3, 4, 9, and $13 \mathrm{had}$ the least proportion of vegetated sites as tall fescue, but the highest proportion of reed canarygrass. Proportions of vegetation species as tall fescue, Kentucky bluegrass, orchardgrass, and broadleaf weeds differed $(P<0.01)$ and proportions of reed canarygrass and sedge tended to differ $(P<0.08)$ between sampling intervals (data not shown). The proportion of tall fescue in the pastures was greater in November than in May, July, and September. However, the proportions of Kentucky bluegrass and orchardgrass were greater in May than in July, September, and November. Proportions of broadleaf weeds were greater in July and September than in May, which was also greater than November. Proportion of reed canarygrass tended to be greater in May than in July and September, but was not different from November. As expected, because of forage type and growth characteristics, the proportions of sedge observed in the pastures tended to be greater during the warm 
Table 3. Proportions of bare soil, proportions of manure-covered ground, forage sward heights, and proportions of vegetated sites as tall fescue, reed canarygrass, legumes, sedge, broadleaf weeds, and shrubs within $15.2 \mathrm{~m}$ of streams in pastures during the 3-yr study.

\begin{tabular}{|c|c|c|c|c|c|c|c|c|c|}
\hline Pasture $^{1}$ & Bare soil & $\begin{array}{l}\text { Manure-covered } \\
\text { ground }\end{array}$ & $\begin{array}{c}\text { Forage } \\
\text { sward height }\end{array}$ & Tall fescue & $\begin{array}{c}\text { Reed } \\
\text { canarygrass }\end{array}$ & Legumes & Sedge & Broadleaf weeds & Shrubs \\
\hline & \multicolumn{2}{|c|}{---------------- (\%) --------------- } & (cm) & 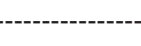 & 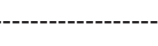 & $---(\%$ of ve & sites)-- & 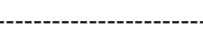 & 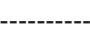 \\
\hline Pasture 1 & 13.4 bcde $^{2}$ & $1.0 \mathrm{a}$ & $5.7 \mathrm{~d}$ & $70.9 \mathrm{ab}$ & $3.0 \mathrm{c}$ & 3.2 bc & $0.7 \mathrm{~b}$ & $12.2 \mathrm{bcd}$ & $2.8 \mathrm{bcd}$ \\
\hline Pasture 2 & $16.9 \mathrm{bc}$ & $0.5 \mathrm{abcd}$ & $6.5 \mathrm{~cd}$ & $58.2 a b c$ & $5.5 \mathrm{c}$ & $5.1 \mathrm{bc}$ & $0.8 \mathrm{~b}$ & $24.0 a b$ & $9.0 \mathrm{a}$ \\
\hline Pasture 3 & 6.0 ef & $0.0 \mathrm{~d}$ & $23.4 \mathrm{a}$ & $8.3 \mathrm{e}$ & $67.8 \mathrm{a}$ & $0.1 \mathrm{c}$ & $0.7 \mathrm{~b}$ & $22.6 \mathrm{bc}$ & $5.5 a b$ \\
\hline Pasture 4 & 8.5 def & $0.6 a b c$ & $13.8 \mathrm{bc}$ & 25.9 de & $65.8 \mathrm{a}$ & $2.6 \mathrm{bc}$ & $2.6 a b$ & $2.1 \mathrm{~d}$ & $0.4 \mathrm{~cd}$ \\
\hline Pasture 5 & 12.0 cde & $0.3 \mathrm{~cd}$ & $6.3 \mathrm{~cd}$ & 76.2 a & $2.6 \mathrm{C}$ & $1.8 \mathrm{c}$ & $0.8 \mathrm{~b}$ & 12.9 bcd & $4.4 \mathrm{bc}$ \\
\hline Pasture 6 & $31.3 \mathrm{a}$ & $0.2 \mathrm{~cd}$ & $4.5 \mathrm{~d}$ & $54.0 \mathrm{bc}$ & $9.1 \mathrm{c}$ & $9.2 a b c$ & $0.4 \mathrm{~b}$ & 20.9 bc & $3.6 \mathrm{bcd}$ \\
\hline Pasture 7 & 17.3 bc & $1.0 \mathrm{a}$ & $5.9 \mathrm{~d}$ & $69.8 \mathrm{ab}$ & $5.1 \mathrm{C}$ & $18.7 \mathrm{a}$ & $0.0 \mathrm{~b}$ & $2.2 \mathrm{~d}$ & $0.2 \mathrm{~d}$ \\
\hline Pasture 8 & $14.3 \mathrm{bcd}$ & $0.6 \mathrm{abc}$ & $5.6 \mathrm{~d}$ & 53.2 bc & $10.5 \mathrm{c}$ & 3.9 bc & $1.2 \mathrm{~b}$ & 21.1 bc & $4.9 a b$ \\
\hline Pasture 9 & 7.3 def & $0.2 \mathrm{~cd}$ & $16.5 \mathrm{ab}$ & $16.2 \mathrm{e}$ & $62.9 \mathrm{a}$ & $1.1 \mathrm{c}$ & $4.6 \mathrm{a}$ & $12.5 \mathrm{bcd}$ & $0.6 \mathrm{~cd}$ \\
\hline Pasture 10 & 20.2 b & $0.4 \mathrm{bcd}$ & $6.2 \mathrm{~cd}$ & $44.9 \mathrm{~cd}$ & $2.8 \mathrm{c}$ & 6.2 bc & $0.6 \mathrm{~b}$ & $35.6 \mathrm{a}$ & $5.6 a b$ \\
\hline Pasture 11 & $36.6 \mathrm{a}$ & $0.9 \mathrm{ab}$ & $2.4 \mathrm{~d}$ & $74.0 \mathrm{a}$ & $0.8 \mathrm{c}$ & $6.0 \mathrm{bc}$ & $0.2 \mathrm{~b}$ & $10.5 \mathrm{~cd}$ & $3.0 \mathrm{bcd}$ \\
\hline Pasture 12 & $16.7 \mathrm{bc}$ & $0.6 a b c$ & $4.7 \mathrm{~d}$ & $49.1 \mathrm{c}$ & $7.8 \mathrm{c}$ & $13.2 a b$ & $0.3 \mathrm{~b}$ & $21.1 \mathrm{bc}$ & $3.7 \mathrm{bcd}$ \\
\hline Pasture 13 & $3.3 f$ & $0.0 \mathrm{~d}$ & $24.0 \mathrm{a}$ & $24.7 \mathrm{e}$ & $40.8 \mathrm{~b}$ & $0.1 \mathrm{c}$ & $0.8 \mathrm{~b}$ & $28.7 \mathrm{ab}$ & $3.2 \mathrm{bcd}$ \\
\hline SE & 1.51 & 0.10 & 1.46 & 3.87 & 2.86 & 2.21 & 0.57 & 2.59 & 0.84 \\
\hline
\end{tabular}

${ }^{1}$ Differences among farms were determined by $n=12$.

${ }^{2}$ Within a column, least squares means without a common lowercase letter differ $(P<0.05)$.

seasons of July and September than in November, but were not different from May. Variations in species prevalence imply that cattle selected the more palatable vegetation species, such as Kentucky bluegrass, smooth bromegrass, and orchardgrass early in the growing season, which thereby decreased their presence later in the season. This decrease in palatable species allowed less-palatable and colder-tolerant species such as tall fescue to predominate in the riparian zones of pastures later in the season.

\section{Manure-Covered Ground}

Proportions of manure-covered ground along the stream banks differed $(P<0.05)$ between pastures (Table 3$)$ and sampling intervals (Table 4). The greatest and least proportions of manure-covered ground occurred in November and September, respectively, with measurements in May and July not differing from either month. These differences may have resulted from seasonal differences in precipitation and pasture stocking rates. During the $3 \mathrm{yr}$, above-average rainfall amounts that occurred between the July and September measurements (Fig. 1) may have contributed to an increase of overland flow, decreasing the amount of manure-covered ground observed within the riparian zones in September. The proportion of manure-covered ground

Table 4. Proportion of bare soil, proportion of manure-covered ground, and forage sward heights within $15.2 \mathrm{~m}$ of streams in pastures by period during the 3-yr study.

\begin{tabular}{lccc}
\hline Sampling month & Bare soil (\%) & $\begin{array}{c}\text { Manure-covered } \\
\text { ground }(\%)\end{array}$ & $\begin{array}{c}\text { Forage sward } \\
\text { height }(\mathrm{cm})\end{array}$ \\
\hline May & 16.4 & $0.5 \mathrm{ab}^{1}$ & $11.9 \mathrm{a}$ \\
July & 14.7 & $0.5 \mathrm{ab}$ & $14.1 \mathrm{a}$ \\
September & 16.0 & $0.3 \mathrm{~b}$ & $8.7 \mathrm{~b}$ \\
November & 15.6 & $0.6 \mathrm{a}$ & $3.9 \mathrm{c}$ \\
SE & 0.67 & 0.06 & 0.8 \\
\hline
\end{tabular}

within $15.2 \mathrm{~m}$ of the stream (\%) increased as the stocking rate between measurements (cow-days $\cdot \mathrm{m}^{-1}$ stream) quadratically increased according to the following equation (Fig. 2):

$$
y=0.15+0.18 x-0.0088 x^{2}\left(r^{2}=0.35\right) .
$$

The two pastures with the least amount of manure-covered ground were Pastures 3 and 13, which were ungrazed vegetation buffers at the initiation of the experiment. The vegetation buffers also contained two of the highest proportions of vegetated sites as broadleaf weeds, which may have resulted in a coincidental correlation of a quadratically decreasing percentage of manurecovered ground as the percentage of broadleaf weeds in the vegetation increased:

$$
y=0.77-0.026 x+0.00030 x^{2}\left(r^{2}=0.15\right) .
$$

In addition, manure-covered ground quadratically increased as the percentage of tall fescue increased

$$
y=0.20+0.00081 x+0.000078 x^{2}\left(r^{2}=0.23\right)
$$

but quadratically decreased as the percentage of reed canarygrass increased

$$
y=0.67-0.017 x+0.00015 x^{2}\left(r^{2}=0.17\right)
$$

The greater concentration of cattle manure near the pasture streams in November than September may have also been related to factors affecting distribution within the pasture such as a decrease in the quantity or quality of forage in pasture uplands (Bailey 2005), a decrease in natural off-stream water sources, or a decrease in the ambient temperatures resulting in less heat stress in periods of the late fall than mid- to late summer. Climatic conditions near pasture streams may have been more comfortable for cattle within these areas later in the grazing season combined with less insect annoyance than during the summer grazing. 


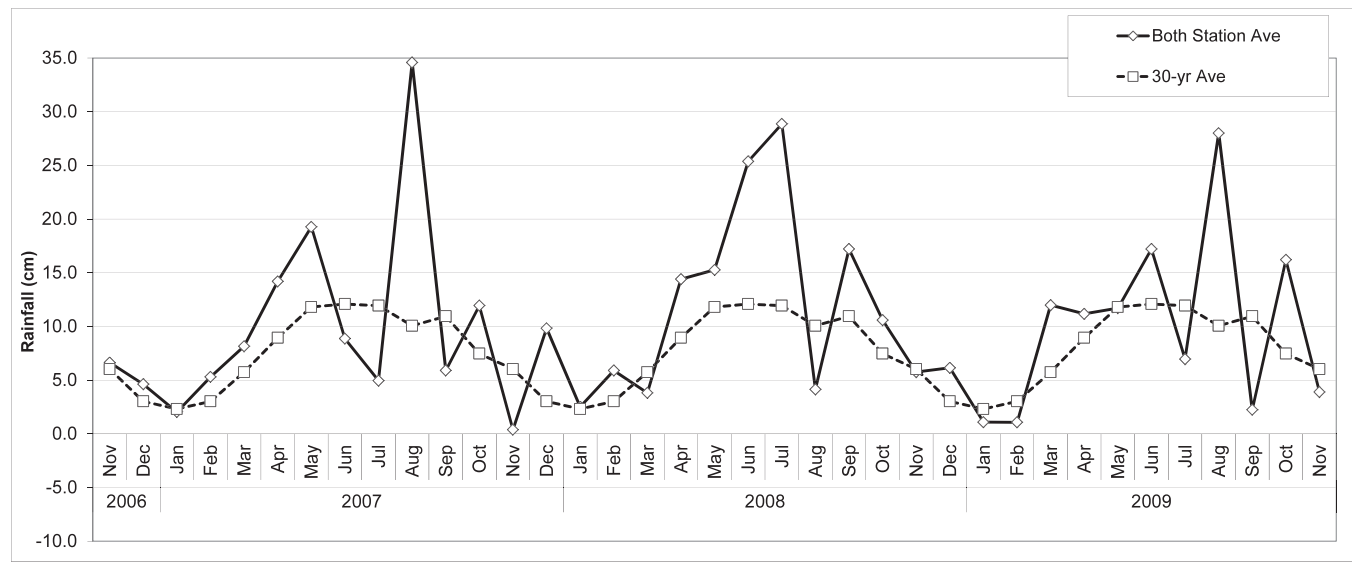

Figure 1. Monthly precipitation over the 3-yr study compared to 30-yr average with monthly departure. Monthly precipitation amounts were averaged between the nearest national weather stations, Chariton $1 \mathrm{E}$ and Allerton, Iowa.

\section{Forage Sward Height}

Mean sward heights, measured with a falling plate meter, were different $(P<0.01)$ between pastures (Table 3$)$ and months (Table 4). Mean sward height decreased from July to November. Stocking rate between measurements $\left(\right.$ cow-days $\cdot \mathrm{m}^{-1}$ stream) was quadratically related to the forage sward height $(\mathrm{cm})$ measured $7.6 \mathrm{~m}$ from the stream (Fig. 3):

$$
y=16.28-4.37 x+0.33 x^{2}\left(r^{2}=0.31\right) .
$$

This relationship implies that stocking rates greater than 1.63 cow-days $\cdot \mathrm{m}^{-1}$ stream during the approximately $60 \mathrm{~d}$ between measurements from May through November or the approximately $180 \mathrm{~d}$ between measurements in November and May or 6.52 cow-days $\cdot \mathrm{m}^{-1}$ stream annually would result in a sward height less than the $10 \mathrm{~cm}$ needed to protect against soil detachment during precipitation and treading events (Clary and Leininger 2000). Although the use of stubble height alone has been reported to be not suitable to predict sediment infiltration (Pearce et al. 1997, 1998), Haan et al. (2006) reported lower quantities and phosphorus loading of runoff from pastures that were rotationally stocked to a residual height of $10 \mathrm{~cm}$ than in pastures continuously stocked to a residual height of $5 \mathrm{~cm}$ in

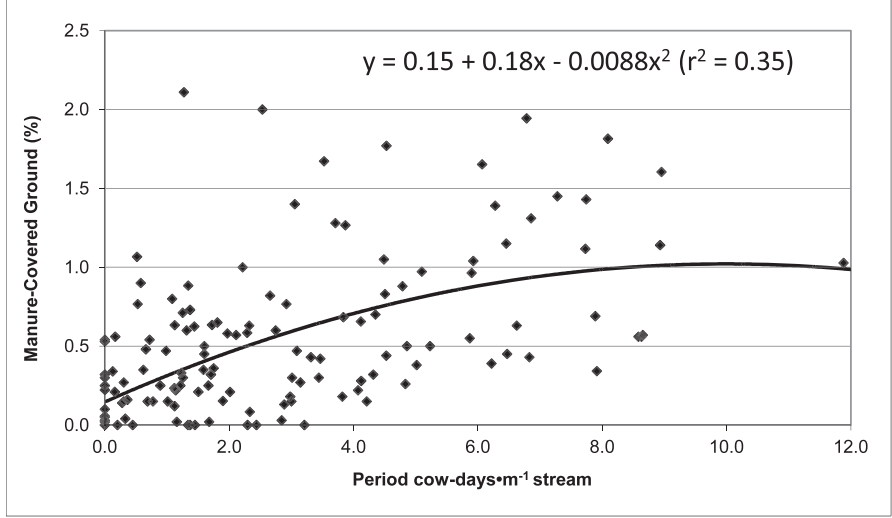

Figure 2. Effect of period stocking rate per stream meter on manurecovered ground (\%) observed within $15.2 \mathrm{~m}$ of a stream. cool-season grass pastures. By maintaining adequate vegetation cover and height, plant vigor may be preserved (Frazier et al. 1998; Clary and Leininger 2000) and reduce NPS pollution from riparian areas of pastures (Warren et al. 1986; Elliott et al. 2002; Reed and Carpenter 2002). In the current study, forage sward heights within riparian areas of pastures quadratically increased as the proportion of reed canarygrass increased

$$
y=4.06+0.40 x-0.0027 x^{2}\left(r^{2}=0.42\right)
$$

but quadratically decreased as the proportion of tall fescue

$$
y=25.57-0.55 x+0.0034 x^{2}\left(r^{2}=0.50\right)
$$

and legumes

$$
y=12.75-0.94 x-0.019 x^{2}\left(r^{2}=0.17\right)
$$

increased. These results infer that the presence of tall sodforming grasses near pasture streams may be more effective at preventing NPS of pasture streams than shorter bunchgrasses. However, similar to broadleaf weeds, this relationship might relate to absence of grazing, as two of the four pastures with the greatest proportions of reed canarygrass were ungrazed buffers.

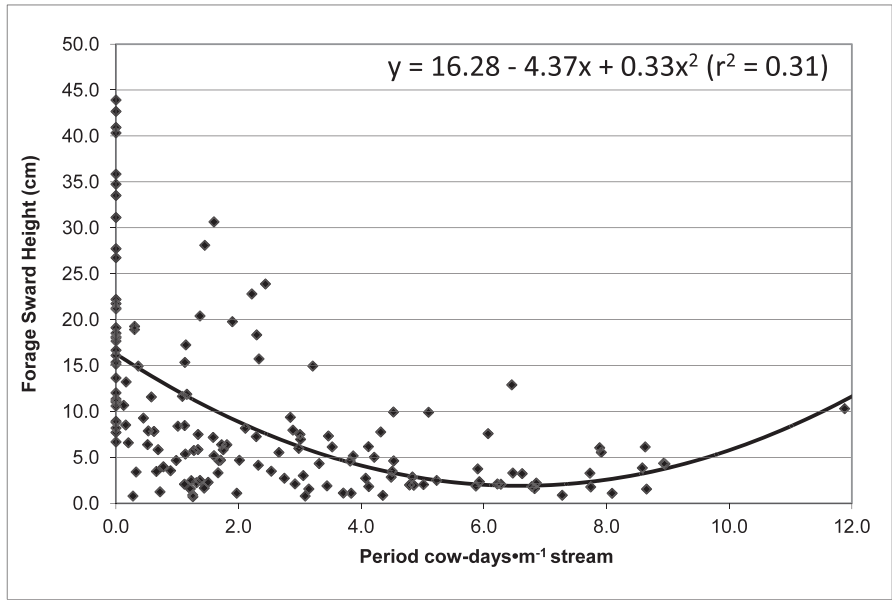

Figure 3. Effect of period stocking rate per stream meter on forage sward height $(\mathrm{cm})$ observed within $15.2 \mathrm{~m}$ of a stream. 


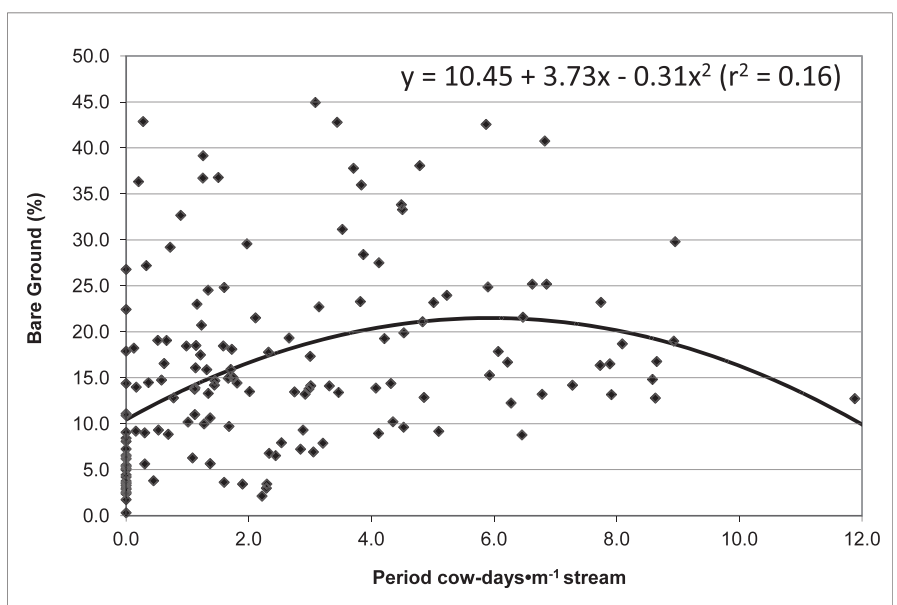

Figure 4. Effect of period stocking rate per stream meter on bare ground $(\%)$ observed within $15.2 \mathrm{~m}$ of a stream.

\section{Bare Soil}

Proportions of bare soil along the stream banks differed among pastures $(P<0.01$; Table 3$)$, but did not differ $(P>0.10$; Table 4) between sampling intervals. The proportion of bare soil along the stream banks was not related to the stocking rate between measurements (cow-days $\cdot \mathrm{m}^{-1}$ stream; Fig. 4):

$$
y=10.45+3.73 x-0.31 x^{2}\left(r^{2}=0.16\right) .
$$

This result may have been related to the measurement method. Because the proportion of bare soil was determined perpendicular to the stream edge, these measurements included eroded stream banks with variable lengths along with areas above the crest of the bank. Therefore, the bare soil measurements were likely affected by factors related to stream bank erosion.

The proportions of bare soil in riparian areas of pastures were related to the botanical composition of species within riparian areas of the pastures evaluated. Similar to sward height, the proportions of bare ground in riparian areas quadratically increased as the proportion of tall fescue

$$
y=3.83+0.40 x-0.0024 x^{2}\left(r^{2}=0.24\right)
$$

and legumes

$$
y=12.13+1.12 x-0.024 x^{2}\left(r^{2}=0.18\right)
$$

increased, but quadratically decreased as reed canarygrass increased

$$
y=21.10-0.37 x+0.0023 x^{2}\left(r^{2}=0.35\right)
$$

as would be indicative of the type and growth rates of the forages observed.

\section{Stream Bank Erosion Rates.}

Across the 3 -yr study, net erosion rate was greater $(P<0.05)$ during the winter through early spring than either the late spring through early summer or late summer through fall periods (Fig. 5). During the current study, above-normal precipitation occurred prior to entering or exiting the winters,

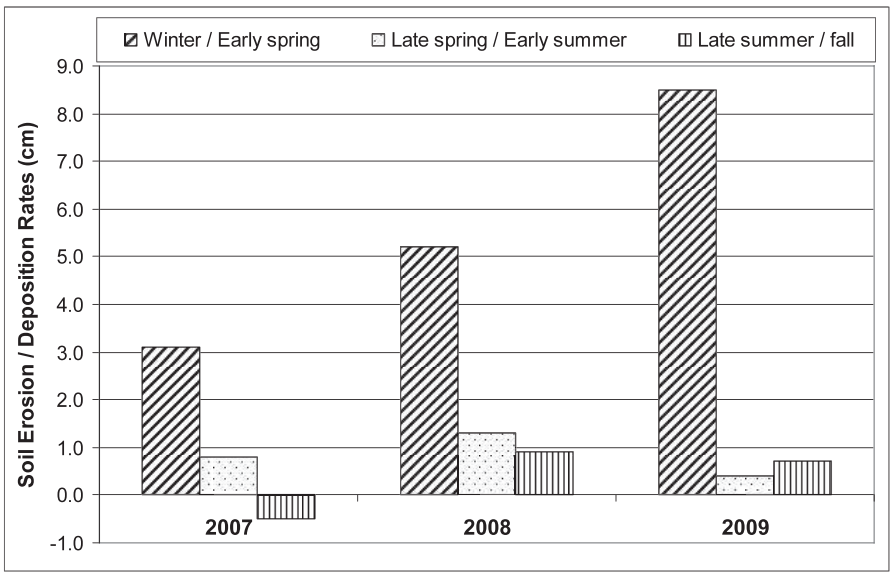

Figure 5. Seasonal stream bank erosion/deposition rates occurring from 2007 to 2009.

which when combined with preexisting saturated stream banks during the periods with the greatest freeze-thaw activity likely resulted in the winter through early spring period having the greatest amounts of stream bank erosion.

Stocking rate between measurements (cow-days $\cdot \mathrm{m}^{-1}$ stream) was not correlated to net stream bank erosion rates (cm; Fig. 6):

$$
y=3.28-0.48 x-0.026 x^{2}\left(r^{2}=0.06\right) .
$$

Therefore, it seems that natural factors of hydrology such as stream stage flow and rainfall characteristics (Tufekcioglu 2010) had larger effects on stream bank erosion than a direct, immediate effect of cattle traffic did in this study. The amounts of precipitation between measurements $(\mathrm{cm})$ accounted for $15 \%, 24 \%$, and $44 \%$ of the variation in net stream bank erosion rates $(\mathrm{cm})$ during the winter through early spring

$$
y=5.60+0.15 x-0.0036 x^{2}
$$

late spring through early summer

$$
y=3.02-0.17 x+0.0025 x^{2}
$$

and late summer through fall seasons

$$
y=-2.54+0.11 x-0.00058 x^{2}
$$

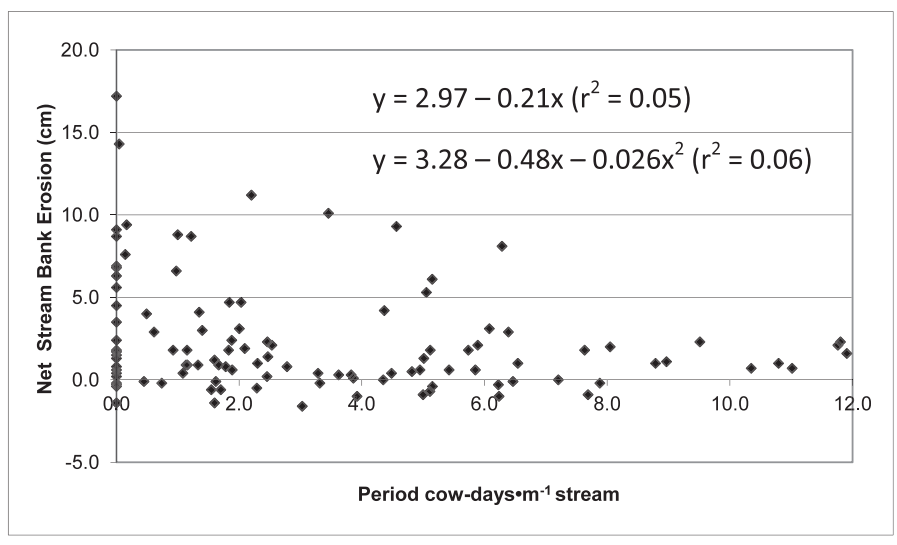

Figure 6. Effect of period stocking rate per stream meter on period net stream bank erosion rates. 
Watershed size that drained through each of the 13 pastures accounted for over $68 \%$ of the variation in percentage of bare soil on the stream banks

$$
y=4.59+0.013 x-0.000015 x^{2}
$$

but watershed size did not impact $(P>0.10)$ stream bank erosion along the riparian zones of pastures.

\section{DISCUSSION}

It can be inferred by these results that reducing the stocking rate or altering the distribution of grazing cattle will reduce the risks of polluting pasture streams by reducing manure concentration and maintaining forage height to minimize nutrient transport in precipitation runoff. Differences in manure distribution between seasons and pastures in this study could have resulted from interactions between stocking rate and natural factors such as rainfall in the riparian zones of pastures that altered cattle distribution and transported manure into pasture streams. Cattle distribution patterns are representative of manure nutrient distribution throughout grazed pastures (White et al. 2001; Ballard and Krueger 2005; Haan et al. 2010). Fecal loads have been reported to be greater near cattle attractants of salt, mineral, or energy/protein supplements implying that these attractants may be used to reduce fecal loads in pasture riparian areas (Tate et al. 2003; Bailey et al. 2008a, 2008b). The attractants may be more effective in altering cow distribution during the dry seasons than during wet seasons (Tate et al. 2003). During wet seasons, an increase in watering locations other than streams reduced congregation of cattle near water sources and thus decreased the proportion of fecal deposits located near attractant areas. With above-normal rainfall amounts from July to September of this study, similar conditions may have resulted in the observed decrease in the proportion of manure-covered ground near pasture streams. Furthermore, during the periods of above-normal rainfall throughout the study, an increase in overland flow may have dispersed some fecal deposits, reducing the percentage of observed manure-covered ground in September, but increasing the risk of water quality impairment (Davies et al. 2004).

Heavily stocked pastures may result in the loss of vegetation cover and promote accumulation of manure near streams (Line 2003; Tate et al. 2003; Hubbard et al. 2004). Cattle may congregate near pasture streams to obtain water and shade for thermoregulation (Kauffman and Krueger 1984; Bailey 2005; Franklin et al. 2009) as temperature (McIlvain and Shoop 1971; Zuo and Miller-Goodman 2004; Haan et al. 2010), relative humidity (Black Rubio et al. 2008), and solar radiation (Tucker et al. 2008) increase or as seasons change (Tate et al. 2003). Cattle distribution is affected by factors of pasture size and shape, shade distribution, and forage quality and quantity (Bailey 2005; Haan et al. 2010; Bear 2011). Because stocking rate was not related to bare soil and only weakly related to forage sward height in this study, factors affecting cattle distribution and congregation may be as or more important than stocking rate in their impacts on the physical characteristics of riparian areas.

Because there were no differences between months in the proportion of bare soil in the riparian areas of pastures, nonvegetated areas within riparian areas may contribute to risks of sediment loading of streams year-round. The proportion of bare soil is a major factor associated with soil erosion (Russell et al. 2001; Haan et al. 2006). Not surprisingly, concentration of sediment in surface runoff has been linearly related to the amount of bare ground of a given area, as exposed soil is more susceptible to soil detachment by overland flow (Hofman and Ries 1991; Elliott et al. 2002; Persyn et al. 2004) and erosive energy of raindrops (Young and Wiersma 1973; Morgan 1978; Kinnell 2005). As a result, bare ground in riparian areas of pastures may contribute significant sediment and phosphorus loads to surface waters during heavy rainfall events (Line et al. 2000; Byers et al. 2005; Butler et al. 2006). Although stocking rate did not affect the proportion of bare ground within $15.2 \mathrm{~m}$ of pasture streams in the current study, measuring bare ground from each stream's edge likely confounded the effects of cow traffic on the proportion of bare ground with those caused by precipitation runoff and erosive energy of the stream flow (Tufekcioglu 2010). These natural events may impact the proportion of bare ground in riparian areas of pastures, specifically in stream banks, regardless of cattle presence or absence from these areas.

Stream bank erosion rates, eroded bank length, and sediment loading of streams along riparian areas and stream hydrology are impacted by grazing, wildlife herbivory (Fritz et al. 1999), and land use of the area (Trimble 1994; Zaimes et al. 2004, 2008). However, the current study found only a minimal impact of stocking rates between measurements on net stream bank erosion rates at each measurement date. Therefore, the effects of grazing on stream bank erosion may not be immediate and additional environmental conditions and factors may have contributed to the observed erosion rates. Within the current study, the greatest amount of erosion occurred during the winter/early spring period, which is similar to the results of Buckhouse et al. (1981) and Zaimes et al. (2004). Higher rates of erosion that occurred during this period may have resulted from seasonal effects preceding winter causing saturated stream banks and short vegetation cover. During the study, nearly two-thirds, or $23 \mathrm{mo}$, had above normal rainfall whereas nearly only a third, or 14 mo, experienced below normal rainfall. The study was preceded by $3 \mathrm{yr}$ with below normal precipitation compared to the $30-y r$ average of $93.4 \mathrm{~cm}$. As a result of little change in land management, observed stream bank erosion was believed to be related to the high number of rainfall and storm events and accounted for severity and widening of the streams observed within the watershed.

\section{MANAGEMENT IMPLICATIONS}

These results imply that increasing stocking rate will result in increased manure-covered ground and decreased forage sward heights in riparian zones of Midwestern pastures, which may increase the risks of nutrient and sediment loading in precipitation runoff. These factors may be managed by reducing pasture stocking rate or using practices that alter cow distribution. These practices would be particularly important in the fall to maintain adequate forage sward height and minimize manure concentration near pasture streams to prevent sediment and nutrient transport in spring snowmelt in addition to reducing the risks of stream bank erosion. However, the immediate effects of stocking rate on the proportion of bare soil adjacent to streams and net stream bank erosion are small. 


\section{ACKNOWLEDGMENTS}

The authors would like to thank the cooperating producers for the opportunity to work on their farms and for recording stocking books; Joe Sellers, Mark Fehseke, Scott Couchman, and the personnel in the Rathbun Land and Water Alliance for their assistance with this project; Jon Hobbs for statistical consultation; and the undergraduate and graduate students who assisted with data collection in this study.

\section{LITERATURE CITED}

Alderfer, R. B., and R. R. Robinson. 1947. Runoff from pastures in relation to grazing intensity and soil compaction. Journal of the American Society of Agronomy 39:948-958.

Alexander, R. B., R. A. Smith, G. E. Schwarz, E. W. Boyer, J. V. Nolan, and J. W. BrakeBill. 2008. Differences in phosphorus and nitrogen delivery to the Gulf of Mexico from the Mississippi River basin. Environmental Science Technology 42:822-830.

ALLeN, V. G. 1991. Terminology for grazing lands and grazing animals. Blacksbury, VA, USA: Pocahontas Press. 38 p.

Anderson, D. R., J. L. Laake, B. R. Crain, and K. P. Burnham. 1979. Guidelines for line transect sampling of biological populations. The Journal of Wildlife Management 43:70-78.

BAlLEY, D. W. 2005. Identification and creation of optimum habitat conditions for livestock. Rangeland Ecology \& Management 58:109-118.

Balley, D. W., H. C. VanWagoner, R. Weinmeister, and D. Jensen. 2008a. Evaluation of low-stress herding and supplemental placement for managing grazing in riparian and upland areas. Rangeland Ecology \& Management 61:26-37.

Balley, D. W., H. C. VanWagoner, R. Weinmeister, and D. Jensen. 2008b. Comparison of low-moisture blocks and salt for manipulating grazing patterns of beef cows. Journal of Animal Science 86:1271-1277.

Ballard, T. M., And W. C. Krueger. 2005. Cattle and salmon I: cattle distribution and behavior in a northeastern Oregon riparian ecosystem. Rangeland Ecology \& Management 58:267-273.

BEAR, D. A. 2011. Pasture management effects on nonpoint source pollution of Midwestern watersheds [thesis]. Ames, IA, USA: Iowa State University. 215 p.

Belsky, A. J., A. Matzke, and S. Uselman. 1999. Survey of livestock influences on stream and riparian ecosystems in the western United States. Journal of Soil and Water Conservation 54(1):419-431.

Black Rubio, C. M., A. F. Cibils, R. L. Endecott, M. K. Petersen, and K. G. Boykin. 2008. Piñon-juniper woodland use by cattle in relation to weather and animal reproductive state. Rangeland Ecology \& Management 61:394-404.

Buckhouse, J. C., J. M. Skovin, and R. W. Knight. 1981. Stream bank erosion and ungulate grazing relationships. Journal of Range Management 34:339-340.

Butler, D. M., D. H. Franklin, N. N. Ranells, M. H. Poore, and J. T. Green, JR. 2006. Ground cover impacts on sediment and phosphorus export from manured riparian pasture. Journal of Environmental Quality 35:2178-2185.

Byers, H. L., M. L. Cabrera, M. K. Matthews, D. H. Franklin, J. G. Andrae, D. E. Radclifee, M. A. McCann, H. A. Kuykendall, C. S. Hoveland, and V. H. Calvert II. 2005. Phosphorus, sediment, and Esherichia coli loads in unfenced streams of the Georgia Piedmont, USA. Journal of Environmental Quality 34:2293-2300.

Canfield, R. H. 1941. Application of the line interception method in sampling range vegetation. Journal of Forestry 39:388-394.

Carlassare, M., and H. D. Karsten. 2002. Species contribution to seasonal productivity of a mixed pasture under two sward grazing height regimes. Agronomy Journal 94:840-850.

Clary, W. P., and W. C. Leininger. 2000. Stubble height as a tool for management of riparian areas. Journal of Range Management 53:562-573.

Clary, W. P., C. I. Thornton, and S. R. Авт. 1996. Riparian stubble height and recovery of degraded streambanks. Rangelands 18:137-140.

Clary, W. P., and B. F. Webster. 1990. Riparian grazing guidelines for the Intermountain region. Rangelands 12:209-212.

Davies, C. M., C. M. Ferguson, C. Kaucner, M. Krogh, N. Altavilla, D. A. Deere, and N. J. Ashbolt. 2004. Dispersion and transport of Cryptosporidium oocysts from fecal pats under simulated rainfall events. Applied and Environmental Microbiology 70:1151-1159.

De Baets, S., J. Poesen, A. Knapen, G. G. Barberá, and J. A. Navarro. 2007. Root characteristics of representative Mediterranean plant species and their erosionreducing potential during concentrated runoff. Plant and Soil 294:169-183.

Elliott, A. H., Y. Q. Tian, J. C. Rutherford, and W. T. Carlson. 2002. Effect of cattle treading on interrill erosion from hill pasture: modelling concepts and analysis of rainfall simulator data. Australian Journal of Soil Research 40:963-976.

Franklin, D. H., M. L. Cabera, H. L. Byers, M. K. Matthews, J. G. Andrae, D. E. Radcliffe, M. A. McCann, H. A. Kuykendall, C. S. Hoveland, and V. H. Calvert II. 2009. Impact of water troughs on cattle use of riparian zones in the Georgia Piedmont, USA. Journal of Animal Science 87:2151-2159.

Frasier, G. W., M. J. Trlica, W. C. Leininger, R. A. Pearce, and A. Fernald. 1998. Runoff from simulated rainfall in 2 montane riparian communities. Journal of Range Management 51:315-322.

Fritz, K. M., W. K. Dodds, And J. Pontius. 1999. The effects of bison crossings on the macroinvertebrate community in a tallgrass prairie stream. American Midland Naturalist 141:253-265.

Griffith, G. E., J. M. Omernik, T. F. Wilton, and S. M. Pierson. 1994. Ecoregions and subregions of lowa: a framework for water quality assessment and management. The Journal of the lowa Academy of Science 101:5-13.

Haan, M. M., J. R. Russell, J. R. Davis, and D. G. Morrical. 2010. Grazing management and microclimate effects on cattle distribution relative to a cool season pasture stream. Rangeland Ecology \& Management 63:572-580.

Haan, M. M., J. R. Russell, W. J. Powers, J. L. Kovar, and J. L. Benning. 2006. Grazing management effects on sediment and phosphorus in surface runoff. Rangeland Ecology \& Management 59:607-615.

Hermann, M. L., J. R. Russell, and S. K. Barnhart. 2002. Evaluation of hay-type and grazing-tolerant alfalfa cultivars in season-long or complementary rotational stocking systems for beef cows. Journal of Animal Science 80:768-779.

Hofman, L., and R. E. Ries. 1991. Relationship of soil and plant characteristics to erosion and runoff on pasture and range. Journal of Soil and Water Conservation 46:143-147.

Hooke, J. M. 1979. An analysis of the processes of river bank erosion. Journal of Hydrology 42:39-62.

Hubbard, R. K., G. L. Newton, And G. M. Hill. 2004. Water quality and the grazing animal. Journal of Animal Science 82:E255-E263.

ISENHART, T., AND V. SitZMAN. 2001. Assessment of the ecological integrity of stream corridors in the Rathbun Lake watershed using the stream visual assessment protocol. Appendix E. In: M. Braster, T. Jacobson, and V. Sitzmann [eds.]. Assessment and management strategies for the Rathbun Lake watershed. Centerville, IA, USA: Rathbun Land and Water Alliance Center. 31 p.

Kauffman, J. B., and W. C. Krueger. 1984. Livestock impacts on riparian ecosystems and streamside management implications-a review. Journal of Range Management 37:430-438.

Kemp, D. R., And D. L. Michalk. 2007. Towards sustainable grassland and livestock management. Journal of Agricultural Science 145:543-564.

KInNELL, P. I. A. 2005. Raindrop-impact-induced erosion processes and prediction: a review. Hydrological Processes 19:2815-2844.

KLemmedson, J. 0. 1956. Interrelationships of vegetation, soils and range conditions induced by grazing. Journal of Range Management 9:134-138.

Krueger, W. C., M. A. Sanderson, J. B. Cropper, M. Miller-Goodman, C. E. Kelly, R. D. Pieper, P. L. Shaver, M. J. Trlica, V. G. Allen, D. Fisher, M. Havstad, and P. L. Sims. 2002. Environmental impacts of livestock on U.S. grazing lands. Council for Agricultural Science and Technology 22. $16 \mathrm{p}$.

LAWLER, D. M. 1993. The measurement of river bank erosion and lateral channel change: a review. Earth Surface Processes and Landforms 18:777-821.

Lee, J. M., D. J. Donaghy, P. Sathish, and J. R. Roche. 2009. Interaction between water-soluble carbohydrate reserves and defoliation severity on the regrowth of perennial ryegrass (Lolium perenne L.)-dominant swards. Grass and Forage Science 64:266-275.

LINE, D. E. 2003. Changes in a stream's physical and biological conditions following livestock exclusion. Transactions of the American Society of Agricultural Engineers 46:287-293. 
Line, D. E., W. A. Harman, G. D. Jennings, E. J. Thompson, and D. L. Osmond. 2000. Nonpoint-source pollutant load reductions associated with livestock exclusion. Journal of Environmental Quality 29:1882-1890.

Manley, W. A., R. H. Hart, M. J. Samuel, M. A. Smith, J. W. Waggoner, JR., and J. T. Manley. 1997. Vegetation, cattle, and economic responses to grazing strategies and pressures. Journal of Range Management 50:638-646.

Masterman, R., and C. R. Thorne. 1992. Predicting influence of bank vegetation on channel capacity. Journal of Hydraulic Engineering 118:1052-1058.

Mcllvain, E. H., AND M. C. Shoop. 1971. Shade for improving cattle gains and rangeland use. Journal of Range Management 24:181-184.

Miner, J. R., J. C. Buckhouse, And J. A. Moore. 1992. Will a water trough reduce the amount of time hay-fed livestock spend in the stream (and therefore improve water quality)? Rangelands 14:35-38.

Morgan, R. P. C. 1978. Field studies on rainsplash erosion. Earth Surface Processes 3:295-299.

Pearce, R. A., M. J. Trlica, W. C. Leininger, D. E. Mergen, and G. Frasier. 1998. Sediment movement through riparian vegetation under simulated rainfall and overland flow. Journal of Range Management 51:301-308.

Pearce, R. A., M. J. Trlica, W. C. Leininger, J. L. Smith, and G. W. Frasier. 1997. Efficacy of grass buffer strips and vegetation height on sediment filtration in laboratory rainfall simulations. Journal of Environmental Quality 26:139-144.

Persyn, R. A., T. D. Glanville, T. L. Richard, J. M. Laflen, and P. M. Dixon. 2004. Environmental effects of applying composted organics to new highway embankments: part 1. Interrill runoff and erosion. Transactions of the American Society of Agricultural Engineers 47:463-469.

Rathbun Land and Water Alliance. 2001. Backrgound on Rathbun Lake and watershed. In: M. Braster, T. Jacobson, and V. Sitzman [EDS.]. Assessment and management strategies for the Rathbun Lake watershed. Centerville, IA, USA: Rathbun Land and Water Alliance. p. III-1-III-3.

Reed, T., and S. R. Carpenter. 2002. Comparisons of P-yield, riparian buffer strips, and land cover in six agricultural watersheds. Ecosystems 5:568-577.

REYNoLdson, T. B. 1987. Interactions between sediment contaminants and benthic organisms. Hydrobiologia 149:53-66.

Russell, J. R., K. Betteridge, D. A. Costall, And A. D. MacKay. 2001. Cattle treading effects on soil loss and water infiltration. Journal of Range Management 54:184-190.

Sanderson, M. A., D. W. StalR, and M. A. Hussey. 1997. Physiological and morphological responses of perennial forages to stress. Advances in Agronomy 59:171-224.

Schoonover, J. E., B. G. LockABy, And B. S. Helms. 2006. Impacts of land cover on stream hydrology in the West Georgia Piedmont, USA. Journal of Environmental Quality 35:2123-2131.
Self-Davis, M. L., P. A. Moore, JR., T. C. Daniel, D. J. Nichols, T. J. Sauer, C. P. West, G. E. AIKEN, AND D. R. EdWARDs. 2003. Forage species and canopy cover effects on runoff from small plots. Journal of Soil and Water Conservation 58:349-359.

Strahler, A. N. 1957. Quantitative analysis of watershed geomorphology. Transaction of the American Geophysical Union 38:913-920.

Tate, K. W., E. R. Atwill, N. K. Mcdougald, and M. R. George. 2003. Spatial and temporal patterns of cattle feces deposition on rangeland. Journal of Range Management 56:432-438.

TempLE, D. M. 1982. Flow retardance of submerged grass channel linings. Transactions of the American Society of Agricultural Engineers 1982:1300-1303.

Trimble, S. W. 1994. Erosional effects of cattle on streambanks in Tennessee, USA. Earth Surface Processes and Landforms 19:451-464.

TuckeR, C. B., A. R. Rogers, AND K. E. Schütz. 2008. Effect of solar radiation on dairy cattle behaviour, use of shade and body temperature in a pasture-based system. Applied Animal Behavior Science 109:141-154.

TufekCIOGLu, M. 2010. Stream bank soil and phosphorus losses within grazed pasture stream reaches in the Rathbun Watershed in southern lowa [thesis]. Ames, IA, USA: lowa State University. 108 p.

Wang, L. Z., D. M. Robertson, and P. J. GarRison. 2007. Linkages between nutrients and macroinvertebrates and fish assemblages in wadeable streams: implication to nutrient criteria development. Environmental Management 39:194-212.

Warren, S. D., T. L. Thurow, W. H. Blackburn, and N. E. Garza. 1986. The influence of livestock trampling under intensive rotation grazing on soil hydrologic characteristics. Journal of Range Management 39:491-495.

White, S. L., R. E. Sheffield, S. P. Washburn, L. D. King, and J. T. Green, JR. 2001. Spatial and time distribution of dairy cattle excreta in an intensive pasture system. Journal of Environmental Quality 30:2180-2187.

WoLmAn, M. G. 1959. Factors influencing erosion of a cohesive river bank. American Journal of Science 257:204-216.

Young, R., AND J. Wiersma. 1973. The role of rainfall impact in soil detachment and transport. Water Resources Research 9:1629-1636.

Zaimes, G. N., R. C. Schultz, And T. M. Isenhart. 2004. Stream bank erosion adjacent to riparian forest buffers, row-crop fields, and continuously-grazed pastures along Bear Creek in central lowa. Journal of Soil and Water Conservation 59:19-27.

Zaimes, G. N., R. C. Schultz, and T. M. Isenhart. 2008. Total phosphorus concentrations and compaction in riparian areas under different riparian landuses of Iowa. Agriculture, Ecosystems and Environment 127:22-30.

Zuo, H., And M. S. Miller-Goodman. 2004. Landscape use by cattle affected by pasture developments and season. Journal of Range Management 57:426-434. 